\title{
ABBREVIATIONS OR TERMS USED IN THE TEXT
}

THESE HAVE been kept to a minimum, for purposes of clarity. Several terms are not readily translated and therefore deserve mention.

CEN

Great Committee

Oficial Mayor

\section{Political Boss}

UNAM
National Executive Committee (Comité Ejecutivo Nacional), used by the government parties to designate its executive administrative structure

(Gran Comisión), the most important committee in the Chamber of Deputies, made up of the head of each state delegation. The president of this body would have the status of a majority leader

No logical translation exists for this position in the national and state executive branches. At the national level, this post is often third in rank, in prestige and power, after that of a secretary and subsecretary

(Jefe Político), although we use the term in political language to refer to a machine-style politician, such as Richard Daley of Chicago, in the biographies, during the Porfiriato, this was a formal political post, below that of governor, which had executive powers at the local level or over large regions, including territories, such as Nayarit, which later became states.

National Autonomous University of Mexico or National University (Universidad Nacional Autónoma de Méxicol 
THIS PAGE INTENTIONALLY LEFT BLANK 